\title{
Hegel, the Struggle for Recognition, and Robots
}

\author{
Nolen Gertz \\ Assistant Professor of Applied Philosophy, University of Twente \\ n.gertz@utwente.nl
}

\begin{abstract}
While the mediational theories of Don Ihde and Peter-Paul Verbeek have helped to uncover the role that technologies play in ethical life, the role that technologies play in political life has received far less attention. In order to fill in this gap, I turn to the mediational theory of Hegel, as Hegel shows how the mediated nature of experience is vital to understanding the development of both ethical and political life. Through examples found in the military, in particular concerning the relationship between explosive ordnance detonation (EOD) soldiers and robots, I illustrate how Hegel's analysis of the "struggle for recognition" can be used to understand human-technology relations from a political perspective. This political perspective can consequently help us to appreciate how technologies come to have a role in political life through our ability to experience solidarity with technology, a solidarity that is experienced by users due to the recognition of technologies as serving roles in society that I describe as functionally equivalent to the social roles of the user. The realization of this functional equivalence allows users to learn how they are perceived and respected by society through the experience of how functionally equivalent technologies are perceived and respected. Consequently, I conclude by focusing on the Dallas Police Department having turned an EOD robot from a life-saving to a life-taking device in order to show why Hegel is necessary for helping us to understand the political significance of recognizing and of misrecognizing technologies.
\end{abstract}

Keywords: Hegel; Mediation Theory; Ethics of Technology; Politics of Technology; Robotics

\section{Introduction}

On July 8, 2016, the Dallas Police Department equipped an explosive ordnance detonation (EOD) robot with a bomb in order to kill a sniper. Such a tactic had never before been used by the police, but, according to at least one legal expert, this event was not "a legal problem" (Fountain and Schmidt 2016). In other words, as the police are trained and permitted to use lethal force in a situation such as the Dallas PD faced, the means used to achieve those ends are not meaningful from a legal perspective. To divorce means from ends in this way is to believe that technologies are themselves not meaningful, that they are merely neutral tools only made meaningful by the actors using them. However, if technologies are not neutral, if technologies are 
not merely means to an end, then this perspective is not only wrong, but dangerous, particularly as "other law enforcement officials supported the decision, suggesting they could take a similar approach" (Fountain and Schmidt 2016), suggesting that they too are both able and willing to turn a life-saving device into a life-taking device.

The argument that technologies play an active rather than neutral role in ethical life is not new. Following the postphenomenological investigations of Don Ihde into "human-technology relations" (Ihde 1990), Peter-Paul Verbeek has endeavored to show that Ihde's "empirical turn" in philosophy of technology must be followed by an "ethical turn" (Verbeek 2011: 160). However, as others (Boshuijzen-van Burken 2016) have argued, while this ethical turn is necessary for appreciating the role that technologies play in ethical life, it is insufficient for appreciating the role that technologies play in political life. To fill in this gap in the mediational theories of Ihde and Verbeek, I will turn to another mediational theorist, G. W. F. Hegel, as Hegel's mediational theory focuses on the role that mediation plays in the development of both ethical and political life.

As Mark Coeckelbergh (2015) has pointed out, Hegel, and in particular his so-called "master/slave dialectic," has recently become central in debates over the dangers of technology owing to the fears that technologies will soon enslave us. What I intend to show in this article is that such an appropriation of Hegel's philosophy misses the true value of Hegel's insights for understanding human-technology relations, as what is vital is not determining who is the master and who is the slave (Bryson 2010; Wallach 2015; Floridi 2017), but rather what it means to recognize that humans engage with technologies in such a dialectical relationship.

The master/slave dialectic is but one moment in Hegel's larger account of the development of ethical and political life, a development that revolves around the "struggle for 
recognition" (Hegel 1977: 114). By taking seriously the idea that humans can, and do, engage with technologies in the struggle for recognition we can see that technologies mediate both our ethical and our political life. This mediation occurs not because technologies are useful, nor because we anthropomorphize them, but because we can experience "solidarity" (Honneth 1995: 91) with technologies, particularly those technologies that occupy roles in society that are functionally equivalent to our own social roles. Focusing on human-technology relations in the military, and in particular on the relations between EOD teams and EOD robots, we can see how this solidarity takes place, and better understand the ethical and political significance of recognizing, and of misrecognizing, technologies.

\section{From the Mediation of Ethical Life to the Mediation of Political Life}

In the move from the descriptive analyses of human-technology relations found in the postphenomenology of Don Ihde to the normative analyses of human-technology relations found in the mediation theory of Peter-Paul Verbeek, a seemingly insurmountable problem arises in the form of "multistability" (Ihde 1990). Multistability is arguably the central concept of postphenomenology, what enables it to move beyond the totalizing visions of technology espoused by both technology utopianists and technology determinists (Rosenberger and Verbeek 2015: 25-26). By arguing that the essence of technology is to have no essence, that technologies only become what they are in the context of their use, postphenomenology shows that we cannot make predictions about technologies, but must instead investigate how particular technologies come to have particular "stabilities" for particular users in particular situations. As the name suggests, postphenomenology takes from its forebear in Husserlian phenomenology the project of philosophy as a rigorous descriptive science. 
Mediation theory is the attempt to develop a normative framework out of this descriptive science. To develop this normative framework, this new "ethics of technology" that can "hybridize" (Verbeek 2011: 14) the human and the technological, Verbeek first turns to Foucault to open up the space required for showing how ethics can exist in a technologically-mediated world, and then to virtue ethics for the concept of the "good life" which could be used as the ideal for judging potential technological mediations. However, while Foucault can help us to reconceive of ethics in a way that can incorporate the apparent heteronymy of technological mediation into the traditionally-understood autonomy of moral agency, virtue ethics is often criticized for being too vague to give us any concrete guide to achieving the "good life" beyond aiming for "the mean" by avoiding the "extremes" of "deficiency" and "excess," or, in this case, of "conservativism" and "transhumanism" (Verbeek 2011: 157). Indeed, as Aristotle makes clear, "the mean" must always be seen as being "not in the thing itself but relative to us," for which reason others cannot make pronouncements about how we ought to act-including that we ought not to be conservatives or transhumanists - beyond the claim that we ought to have "feelings and actions...at the right time, about the right things, towards the right people, for the right end, and in the right way" (Aristotle 2014: 30). As Aristotle's ethics is a prologue to his politics, this relativism is for Aristotle exactly why we must not be concerned with particular actions but instead with social engineering. As Aristotle concludes, "Perhaps it is not enough, however, that when they are young they get the right upbringing and care; rather, because they must continue and develop their habit when they are grown up, we shall need laws for this as well, and generally for the whole of life" (Aristotle 2014: 198).

What Aristotle shares with Foucault is a recognition that ethics is always formed in relation to politics, that autonomy is always formed in relation to heteronymy. An ethics of 
technology is not sufficient therefore if it does not also incorporate a political dimension, as the "good" of the "good life" is first and foremost socially, not individually, determined. What Foucault and Aristotle help us to realize therefore is that we cannot create an ethics of technology, or any ethical theory whatsoever, out of thin air, but must instead investigate the history of ethical and political life, how and why ethical categories and concepts have developed over time, because we are always already born into an ethical world not of our making.

It is for this reason that if we want to continue to develop philosophy of technology, to, as Verbeek concludes, take "one more turn after the empirical and ethical turn" and carry out "further analysis of the mediating roles of specific technologies in human existence, society, and culture" and develop "an ethical relation to these mediations" (Verbeek 2011: 164-165), then we should turn to the phenomenology of Hegel. In Hegel's Phenomenology of Spirit we find an account of the development of consciousness into self-consciousness that is at the same time an account of the development of ethical and political life. These developments are one in the same for Hegel because the impetus for both is the relationship between the self and the other. For Hegel, the other-whether it be an object or another consciousness-mediates the self's experience of both itself and of the world. It for this reason that it is only through investigating the ongoing development of self-other relations that we can properly understand the development of ethics and politics.

\section{Post (Hegelian) Phenomenology}

Hegel, like Ihde and Verbeek, argues that human experience is always mediated. Unlike Ihde and Verbeek however, Hegel further argues that the nature of experience is not only mediated, but that, precisely because it is mediated, it is also antagonistic. Hegel's 
phenomenology is an analysis of the stages in the process of the development of consciousness that arises through the antagonisms that make up experience. For Hegel these antagonisms are found both in the epistemological and practical aspects of human life. Antagonisms are the driving force behind experience, what makes experience dynamic rather than static, as it is through the experience of oppositions such as between the immediate and the mediated, the particular and the universal, that we are forced to learn and to grow.

Hegel however does not maintain a theoretical/practical dualism, as the stages of consciousness that develop through the antagonistic process of trying to know the world always leads consciousness to a greater knowledge of itself. Consciousness moves along a "necessary advance" (Hegel 1977: 103) from one moment of knowledge to the next, through a dialectical activity, an activity of overcoming the contradictory tensions that we find in experience. It is through this dialectical process, through this sublating that is a "negating and a preserving" (Hegel 1977: 68) of experiential contradictions, that consciousness becomes self-consciousness. As self-consciousness is achieved by consciousness knowing itself, this achievement is only possible when consciousness is able to know itself fully, when it takes up itself as its object, which, according to Hegel, can only occur through the mediation of the other.

I believe it is possible to bring together Hegel and postphenomenology by adapting Hegel's analyses of the encounter between self and other by making the seemingly illicit move ${ }^{1}$

\footnotetext{
${ }^{1}$ For an attempt at a similarly seemingly illicit reappropriation, see David Gunkel (2012: 181-182): "If Levinasian philosophy is to provide a way of thinking otherwise that is able to respond to and take responsibility from other forms of otherness, or to consider and respond to, as John Sallis $(2010,88)$ describes it, 'the question of another alterity,' we will need to use and interpret Levinas's own philosophical innovations in excess of and in opposition to him. We will need, as Derrida $(1978,260)$ once wrote of Georges Bataille's exceedingly careful engagement with the thought of Hegel, to follow Levinas to the end, 'to the point of agreeing with him against himself' and of wresting his discoveries from the limited interpretations that he provided." See also Coeckelbergh (2016: 185): "...we need to have an ethical starting point that at first leaves open the question of machine otherness, that does not start by asking or answering the 'is' question - for instance that does not close down the discussion by arguing that machines are mere machines and that therefore they cannot have otherness; it is through this kind of operation that
} 
to put, in place of the other, not a consciousness, but a technological object. I say seemingly illicit because the actual moments of the encounter as described by Hegel leave open the possibility that the other need not be a consciousness, but only appear to be a consciousness. ${ }^{2}$ According to Hegel, the struggle for recognition begins when consciousness first sees itself in the other, and then recoils at seeming to have both been reduced to an object by the other and at having reduced the other to an object. As Hegel describes, this interaction of self and other initially "appears to self-consciousness" as "extremes which, as extremes, are opposed to one another, one being only recognized, the other only recognizing" (Hegel 1977: 113). At this point, consciousness is "certain of its own self, but not of the other," according to Hegel, because "appearing thus immediately on the scene, they are for one another like ordinary objects...they are, for each other, shapes of consciousness" as "they have not as yet exposed themselves to each other in the form of pure being-for-self, or as self-consciousnesses" (Hegel 1977: 113). In other words, consciousness projects onto the other its own needs and desires, judging the other based only on

\footnotetext{
so much violence has been done to humans and animals, and it seems at least recommendable and desirable that we move on to a different, other kind of thinking." I thank the anonymous reviewer who recommended these texts.

${ }^{2}$ It may appear that we are here confronted with Hegel's version of the classic philosophical problem of "other minds," the problem perhaps best associated with the moment in Descartes' Meditations when he looks out the window and wonders whether those who appear to be people are not in reality merely automatons wearing overcoats. However Hegel's argument here is not that I know my own mind and simply do not have equivalent access to the mind of the other, but rather that I know neither who I am nor who the other is, for which reason recognition is necessary in order to achieve self-knowledge through the other, through another who is capable of recognizing me (Stern 2002: 73-75). Thus in what follows I will argue that a technological object can fulfill the role of the other not on the basis of some "mental" capacity like artificial intelligence, but rather on the basis of our being able to project what we do know of ourselves onto others in our quest to find out who we are, rather than who the other is. As Stern (2012: 357) concludes in his essay on Hegel and the problem of other minds: "The aim [of Hegel's master/slave dialectic] is not, then, to overcome epistemological worries and to break 'outside the circle of consciousness', but to show that, far from limiting and checking our freedom as it may at first seem, it is only by recognizing others as equal to ourselves that we can in fact realise that freedom." All I need initially know of the other - whether human or technological — is not that the other is intelligent or autonomous, but that the other canunlike the ordinary objects negated in desire - resist the self's desire to negate and present itself instead as itself capable of negation (Stern 2002: 76). Though Hegel argues that "they recognize themselves as mutually recognizing one another"- -suggesting the problem of other minds - what is vital is the argument in the sentence preceding it, that "each is for itself, and for the other, an immediate being on its own account, which at the same time is such only through this mediation (Hegel 1977: 112; emphasis added). It is precisely this emphasis of Hegel on mediation and constitution that I will try to connect with the mediation theories of Ihde and Verbeek.
} 
what it knows of itself, which is why it takes the other to be a threat to itself in the same way that it is a threat to the other. But it is not until acting on the threat by entering into the life-and-death struggle with the other that consciousness can be certain that the other is indeed another consciousness.

For our purposes here the question then is whether technologies could similarly appear to consciousness as being another consciousness, or, to be more precise, of appearing to a self as being both the other who could recognize and elevate the self's consciousness of itself as an independent being, and as the other who could threaten the self's consciousness by reducing it to a mere object for the other. And indeed these are precisely the perspectives one finds in the technological utopianism of transhumanism (Bostrom 2005; Hacking 2013) on the one hand, and in the technological dystopianism of determinism (Heidegger 1977; Ellul 1964) on the other. For transhumanists, it is through technology that we can achieve true mastery, as technology can liberate us from the dependencies and limitations of the body by allowing our consciousnesses to exist freely in the technological realm. For determinists, it is through technology we can achieve instead true servitude, as technology can grow beyond our control, reducing us to not only mere instruments for the ends of technology, but leading us to take up the ends of technology as our ends. In other words, transhumanists see the Wachowski's classic 1999 techno-thriller The Matrix as a utopian vision of being able to upload ourselves into digital playgrounds of our making (Weberman 2002), while determinists see The Matrix as a dystopian vision of humans believing themselves to be free while in reality they have been turned into batteries for our machine masters (Danahay and Rieder 2002).

Postphenomenology overcomes-in the Hegelian sense-this opposition between viewing technology as leading to human mastery and viewing technology as leading to human 
slavery. From the postphenomenological perspective, neither of these views can be seen as either true or false, as instead, because of multistability, it is the unity of these possibilities that is the "truth" of human-technology relations. Though Ihde divides technological mediations primarily into "embodiment relations," "hermeneutic relations," and "alterity relations," he reminds us again and again that these mediations all exist along a "continuum of relations" (Ihde 1990: 73). At one end of the continuum we find in embodiment relations, in the human-technology relations where technologies serve to extend and expand human capabilities beyond the limitations of the body, the dreams of transhumanists. At the other end of the continuum we find in alterity relations, in the human-technology relations where technologies serve to challenge and even oppose human capabilities, the nightmares of determinists.

It is in alterity relations that we would expect to find the perfect candidates for technologies that could serve the role that the other plays for Hegel. As Ihde writes, "Technological otherness is a quasi-otherness, stronger than mere objectness but weaker than the otherness found within the animal kingdom or the human one...there is the sense of interacting with something other than me, the technological competitor" (Ihde 1990: 100). Yet, in his analysis of embodiment relations, Ihde makes clear that the technologies that serve as a "quasime" (Ihde 1990: 107) can at the same time take on some of the properties of the "quasi-other" (Ihde 1990: 98) that we find in alterity relations. Ihde writes:

In extending bodily capacities, the technology also transforms them. In that sense, all technologies in use are non-neutral. They change the basic situation, however subtly, however minimally; but this is the other side of the desire. The desire is simultaneously a desire for a change in situationto inhabit the earth, or even to go beyond the earth - while sometimes inconsistently and secretly wishing that this movement could be without the mediation of the technology. [...] In the wish there remains the contradiction: the user both wants and does not want the technology. The user wants what the technology gives but does not want the limits, the transformation that a technologically extended body implies. There is a fundamental ambivalence toward the very human creation of our own earthly tools. (Ihde 1990: 75-76)

Even in the simple embodiment relation of wearing a pair of glasses, there is this "doubled 
desire" for my eyes to have the power of vision that my glasses make possible, e.g., the desire found in the imagination of cyborg implants replacing my eyes, and for my eyes to have that power of vision without any technology whatsoever, e.g., the desire found in the use of laser surgery to replace my need for glasses. Hence, as Ihde further elaborates, "Such a desire both secretly rejects what technologies are and overlooks the transformational effects which are necessarily tied to human-technology relations. This illusory desire belongs equally to pro- and anti-technology interpretations of technology" (Ihde 1990: 95).

There is to be found in my relations to technologies as "quasi-me" a feeling of the "quasiotherness" of technologies resulting in a "fundamental ambivalence" that can result in either a utopianism that "overlooks" the role of technologies in our lives or in a determinism that "rejects" the role of technologies in our lives. In other words, technologies that work for me, that work as me, present themselves, for that very reason, as both a promise and a threat. It is for this reason that we likewise find similar issues arising in hermeneutic relations, where technologies provide us with new means for interpreting the world. As Ihde writes, "To read an instrument is an analogue to reading a text. But if the text does not correctly refer, its reference object or its world cannot be present" (Ihde 1990: 87). Using the example of the Three Mile Island disaster, Ihde points out that while hermeneutic technologies can serve to provide us access to what would otherwise be too dangerous for us to perceive on our own, they nevertheless create an "enigma position" where "opacity can occur" (Ihde 1990: 87). While hermeneutic technologies offer the promise of otherwise impossible knowledge- - Through hermeneutic relations we can, as it were, read ourselves into any possible situation without being there" (Ihde 1990: 92) — they at the same time offer the threat of betraying our trust, leaving us with the persistent doubt that, to borrow from Gertrude Stein, there is no there there. 
To now return to alterity relations, it is here that Ihde makes most clear that technologies can present themselves to us as not only as a potential threat, but as a direct challenge. As Ihde writes, “...there is the sense of interacting with something other than me, the technological competitor. In competition there is a kind of dialogue or exchange. It is the quasi-animation, the quasi-otherness of the technology that fascinates and challenges" (Ihde 1990: 101). By uniting "quasi-animation" with "quasi-otherness" Ihde is making clear that it is the actions of an object that lead us to see them as either under or beyond our control. In his discussion of the example of the spinning top, Ihde further suggests that the animatedness of an object can lead us to see it as "quasi-autonomous," as if it has a "life of its own" (Ihde 1990: 100). It is for this reason that in alterity relations, unlike in embodiment and hermeneutic relations, technologies do not operate by fading from view to serve as means to some further end, but rather operate by becoming the focus of our attention. Technologies in alterity relations are therefore capable of being both what "fascinates and challenges" as they not only can appear to be independent of us, but, by appearing to be so independent of our will, can, as we have seen, lead us to fear that we will become dependent on them.

According to Ihde this fascinating/challenging dynamic can lead to a love/hate dynamic, as is found for example in our relationships with computers. Computers, whether in the form of desktops and laptops or smartphones and smart TVs, are now so ubiquitous in our daily lives it is likely not a stretch to say that we spend more time with computers than we do with any human being, particularly as more and more our time with other humans is mediated by computers. Yet when the computer no longer fulfills our desires but instead appears to prevent us from doing what we want—whether in the form of a malfunction or of a pop-up message telling us that what we are attempting is not possible - we do not blame and threaten the programmers and engineers 
who created the computer, but the computer itself. Hence, as Ihde points out, though in video games or in hacking we are competing with software designers, we instead see ourselves in competition with technology. Ihde sees our "tendency to fantasize its quasi-otherness into an authentic otherness" as not only "pervasive," but as a "wish-fulfillment desire" similar to what we found in embodiment relations, as "it both reduces or, here, extrapolates the technology into that which is not a technology (in the first case, the magical transformation is into me, in this case, into the other), and at the same time, it desires what is not identical with me or the other" since "the fantasy is for the transformational effects" (Ihde 1990: 106).

What we have found here then is that technologies anywhere along the continuum of human-technology relations can offer us both the promise of fulfilling our dreams of complete freedom and the threat of realizing our nightmares of complete subjection. Our hopes and our fears are inherently contradictory as they are based on ignoring the very mediations that are necessary for technologies to have the possibilities for transformation that create these hopes and fears in the first place. While for Ihde this means that we are unwilling to recognize what technologies are by elevating their quasi-autonomy to the level of genuine autonomy, for Hegel this would mean that we are unwilling to recognize what humans are by elevating our own quasiautonomy to the level of genuine autonomy. Our relations to technologies reveal not only our fantasies about what technologies are, but our fantasies about what we are, revealing further our contradictory hopes and fears about what it means to be human. Consequently, the descriptive analyses of postphenomenology are, from a Hegelian perspective, already normative, as they show that to recognize technologies is to recognize ourselves and to misrecognize technologies is to misrecognize ourselves. Having not yet reached the level of mutual recognition, we thus find ourselves at the stage of the master/slave dialectic, for, which reason, as Ihde puts it, whenever 
technologies do force us to recognize them, our response is, "I must beat the machine or it will beat me" (Ihde 1990: 101).

\section{Technology and Ethical Life}

One may well object at this point that though it appears we have found overlaps between the mediational theories of Hegel and of postphenomenology, these parallels are only formal, not material, for while we can compete with technologies, we cannot enter into life-and-death struggles with technologies (Coeckelbergh 2015: 222). If the master/slave dialectic reveals that we can only recognize and be recognized by those who are able to die, by those who are able to force us to take their claims seriously by staking their lives on those claims, then technologies can neither recognize us nor be recognized by us in an ethically and politically meaningful way. In other words, technologies can play a mediational role in ethical and political life, but they can never play a participatory role in ethical and political life. Or, if they do participate, as Heidegger and Ellul argue, technologies can challenge us, but as we are the only ones in the struggle who are mortal, it is we who must lose the struggle, requiring that we be reduced to the role of slaves while technologies be elevated to masters.

To answer this objection, we can turn to Axel Honneth. Honneth (1995) argues that while it appears that Hegel is providing an existential grounding for ethical and political life, and that this is how many, including Alexandre Kojève (1969), have read Hegel, this is not the only, or even the most satisfactory, reading of Hegel, even if this is indeed how Hegel himself intended his argument to be taken. Honneth writes:

...the reference to the existential dimension of death seems to be completely unnecessary. For it is the mere fact of the morally decisive resistance to its interaction partner that actually makes the attacking subject aware that the other had come to the situation harboring normative expectations in just the way that it had itself vis-à-vis the other. That alone, and not the way in which the other 
asserts its individual rights, is what allows subjects to perceive each other as morally vulnerable persons and, thereby, to mutually affirm each other in their fundamental claims to integrity. In this sense, it is the social experience of realizing one's interaction partner is vulnerable to moral injury - and not the existential realization that the other is mortal - that can bring to consciousness that layer of prior relations of recognition, the normative core of which acquires, in legal relations, an intersubjectively binding form. (Honneth 1995: 48-49)

According to Honneth, what is foundational to ethical relations is not the nature of the struggle between the self and the other, but rather the fact of the struggle. That the other does not merely accede to the normative claims of the self, but instead challenges those claims and puts forth claims of its own, is what reveals both the self and the other to be capable of making claims on each other and of being vulnerable to each other's claims.

What is at question here then is not whether technologies are mortal beings, but rather whether technologies are moral beings, beings who are capable of being both morally authoritative and morally vulnerable. As the moral authoritativeness of technologies has already been argued for persuasively in the work of Ellul (1964), Latour (1992) and of Tromp, Hekkert, and Verbeek (2011), I shall focus here instead on the question of the existence of the moral vulnerability of technologies. To answer this question, we can turn to P. W. Singer's Wired for War, where we find stories of soldiers not only working with robots, naming robots, and of giving robots “"battlefield promotions' and 'Purple Hearts"” (Singer 2009: 338), but of even risking their lives to save robots. Singer writes:

\begin{abstract}
Ironically, these sorts of close human bonds with machines sometimes work against the very rationale for why robots were put on the battlefield in the first place. Unmanned systems are supposed to lower the risks for humans. But as soldiers bond with their machines, they begin to worry about them. Just as a human team would "leave no man behind," for instance, the same sometimes goes for their robot buddies. When one robot was knocked out of action in Iraq, an EOD [explosives ordinance detonation] soldier ran fifty meters, all the while being shot at by an enemy machine gun, to "rescue it." (Singer 2011: 339)
\end{abstract}

It may seem here that soldiers are simply treating their robots like pets, that their concern for the robots is based on empathy from having spent time with these robots, rather than from having recognized these robots as moral beings. However, similar events have been found to occur even 
when soldiers have had no prior experience with the robots, even when the robot was designed for no other purpose than to be destroyed. Singer continues:

This effect even plays out on robot design. Mark Tilden, a robotics physicist at the Los Alamos National Laboratory, once built an ingenious robot for clearing minefields, modeled after a stick insect. It would walk through a minefield, intentionally stepping on any land mines that it found with one of its feet. Then it would right itself and crawl on, blowing up land mines until it was literally down to the last leg. When the system was put through military tests, it worked just as designed, but the army colonel in charge "blew a fuse," recounts Tilden. Describing the tests as "inhuman," the officer ordered them stopped. "The Colonel could not stand the pathos of watching the burned, scarred, and crippled machine drag itself forward on its last leg." (Singer 2011: 339340)

From a postphenomenological perspective, EOD robots are meant to operate for soldiers as a "quasi-me" by transparently extending and replacing the bodily abilities of soldiers. Yet rather than embodiment relations, what Singer describes here are alterity relations, as the robots have become the object of the soldiers' concern, a "quasi-other" that soldiers clearly treat—contrary to expectations and design — as what could be described as a "quasi-comrade." From a Hegelian perspective, soldiers see robots not as mere objects, but as like themselves, treating the robots as they would want to be treated. That soldiers are unwilling to see robots be harmed, and are even willing to risk their lives to save robots, indicates that soldiers have already entered into ethical relations with robots. Soldiers recognize robots as deserving of recognition, not because robots are mortal, but because robots are vulnerable.

What can be learned from these examples is not only that technologies can be recognized as morally vulnerable, but that such recognition is necessary if we are to properly recognize the humans who work with them. It should not surprise us that soldiers are able to see robots as like themselves, as soldiers are, like the robots they work with, put in harm's way in order to protect others. In other words, soldiers serve for civilians the same role that robots are intended to serve for soldiers. Soldiers are, while in combat, in what could be described as embodiment relations with civilians, operating as a "quasi-me" by fading from view while extending and replacing 
civilian capabilities. Yet, as soldiers come to realize, when they return home from war damaged, they are treated, no longer as a "quasi-me," but as something that obtrudes like a broken tool, as a "quasi-other" to be sent to a specialist (psychiatrist) for repairs (PTSD treatment) (Gertz 2014). That we are surprised that soldiers recognize and treat robots as vulnerable highlights to what extent we misrecognize and mistreat soldiers.

From the Hegelian perspective, it is integral to their ethical relations with robots that soldiers not only want to protect robots and are willing to risk their lives for robots, but also that soldiers name robots and give them promotions. As Singer writes, "An affinity for a robot often begins when the person working with it notices some sort of 'quirk,' something about the way it moves, a person or animal it looks like, whatever" (Singer 2011: 338). Singer continues:

\begin{abstract}
Soldiers are not just doing this as a joke, but because they are truly bonding with these machines. Paul Varian, a chief warrant officer who served three tours in Iraq, recounts that his unit's robot was nicknamed "Frankenstein," as it had been made up of parts from other blown-up robots. But after going into battle with the team, Frankenstein was promoted to private first class and even given an EOD badge, "a coveted honor" among the small fraternity of men willing to defuse bombs. "It was a big deal. He was part of our team, one of us. He did feel like family." (Singer 2011: 338)
\end{abstract}

For Hegel, the recognition that another is, like myself, morally authoritative and morally vulnerable, is to recognize the other-not unlike Kant's conception of dignity as based only on our being rational $—$ on solely the level of what is universally shared. Such a generic form of recognition can only produce a generic form of respect as mediated by the creation of generic rights, or as Hegel puts it, "what counts as absolute, essential being is self-consciousness as the sheer empty unit of the person" (Hegel 1977: 291). Yet, because we want to be recognized, not on the level of the universal, not as rational beings, nor as human beings, but as individuals, we will enter into conflict with society again and again in an effort to force society to enlarge the sphere of recognition and gain thereby increasingly individualized rights. It should not surprise us here either then that soldiers, who are given recognition by society only generically—in the form of a 
uniform, a rank, and a serial number, or in being thanked for their service without ever being asked about the specifics of their service-should want to recognize robots in increasingly individualized ways.

It would appear then that the more alienated we feel ourselves to be, the more we identify with technologies. From a Hegelian perspective, this is not simply the result of the marginalized being able to form communities online and thus having technologies mediate their relations with others, nor is this simply the result of anthropomorphization. Rather, those who have been misrecognized, as occurs in the master/slave dialectic, are forced to discover a greater consciousness of self, of what it is about themselves that has been misrecognized, which in turn allows them to discover a greater consciousness of others, of what it is about others that has similarly been misrecognized. As Honneth puts it,

In order to be able to offer a stranger the recognition associated with concern (based on solidarity) for his or her way of life, I need to have already had the shock of an experience that taught me that we share, in an existential sense, our exposure to certain dangers. But the issue of what these risks are that have already linked us together is, in turn, a matter of our shared ideas about what constitutes a successful life within our community. (Honneth 1995: 91)

To recognize a technology as misrecognized by others is not to have discovered some unknown usefulness, nor to see the technology as human, but to recognize that the technology occupies a role in society and for society that is functionally equivalent to the role that one occupies in and for society oneself.

That soldiers should first and foremost experience this "solidarity" — this "synthesis" of the law-centric mode of recognition based on "universally equal treatment," and of the lovecentric mode of recognition based on "emotional attachment and care" (Honneth 1995: 91) should not surprise us, since, as Honneth makes clear, it often takes a "shock" to recognize not only the vulnerabilities of the other, but the vulnerabilities of oneself. Furthermore, Honneth, following Hegel, suggests that the achievement of solidarity is based on the process of "refining" 
the love-centric mode of recognition, the recognition based on individuality, into the law-centric mode of recognition, the recognition based on sociality. I would argue that this is precisely what we find in the movement from soldiers naming, protecting, and honoring EOD robots, to holding funerals for EOD robots, to being offended by the suggestion of replacing rather than repairing EOD robots (Garber 2013), to becoming outraged by the "inhuman" demonstration that robots are created merely to be destroyed. Solidarity then is the basis for the political demand that members of the military — whether human or robotic — be treated not as worthy of replacement, but as worthy of respect.

\section{Conclusion}

I set out in this paper to show that Hegel's phenomenology can help us to better understand the role that technologies play in ethical and political life. By bringing together Verbeek's mediational analyses, Ihde's postphenomenological analyses, and Hegel's dialectical analyses, we can now see that technologies are moral beings, not only because they mediate our practical undertakings, nor only because they can appear to us as objects of promise and of threat, but because technologies can also occupy roles in society that make them worthy of recognition. In the ways that technologies are recognized, those who occupy functionally equivalent social roles can discover how they themselves have been recognized. As technologies come to play greater and more varied roles in society, the recognitions and misrecognitions of technologies will lead more and more people to discover how society views them.

In other words, if we take technologies to be deserving of respect because they appear to be as vital to the realization of social goals as we take ourselves to be, then to see technologies disrespected is to see ourselves as disrespected. Though we may appear to be respected because 
we are accorded rights and responsibilities, we do not know if these rights and responsibilities have any real value in the eyes of society until they have been tested, that is, until we are in a situation that requires that our rights be realized or our responsibilities be appreciated. But because our rights are generic-e.g., the Lockean rights of life, liberty, and the pursuit of property - they are often not put in jeopardy, and so we do not know if they are respected other than by the negative proof of their having not yet been disrespected. Similarly, because our responsibilities are appreciated generically-e.g., through a paycheck-we do not know if there is anything about us, about the particular individuals who are fulfilling those responsibilities, that is being appreciated, other than by the negative proof of our having not yet been fired. To see technologies that we recognize as functionally equivalent to ourselves be destroyed and be replaced is thus to be offered a positive proof of the value, or, to be more specific, the valuelessness, of our rights and responsibilities.

This is why the design and use of technologies has ethical and political importance, not only because technologies mediate our actions, but also because we can recognize ourselves in technologies, and thus the design and use of technologies can be revelatory of how society recognizes us. In the age of mass production, technologies are designed to be useful and yet replaceable. Companies want consumers to both desperately want their products and to be capable of immediately discarding old products in favor of new products. Technologies are therefore marketed as if they are uniquely capable of fulfilling our desires, but they are designed to not be unique, but generic, so that they can be immediately disposed of in favor of another just like it as soon as it breaks or in favor of the newest model as soon as the replacement is ready. In seeing technologies that work with us, for us, and as functionally equivalent to us, having the social value of useful until replaceable, we see ourselves as having the same social value, which 
perhaps explains why so many are filled with anxieties about the perceived dangers to their social role that technologies represent as potential replacements.

That we want to be recognized as having social value, not generically, but individually, is, as we have seen, what can lead us to demand that technologies - the technologies that we recognize as having the equivalent social value as us - be recognized by society individually rather than generically. This is a demand based therefore not on the speculated demand for selfworth that will arise from technologies becoming artificially intelligent beings, but on the social worth of technologies that have already become beings with which we can experience solidarity. Whereas users can recognize technologies individually by appreciating their quirks, giving them names, and by protecting them from harm - as we saw in the example of how EOD teams treat their EOD robots - designers can recognize technologies individually by appreciating how users identify with and respect technologies and by designing technologies accordingly. By creating technologies that are not mass produced and generic, that are not intended to be merely useful and replaceable, designers can show users that they have recognized not only the social value of the technologies, but of the users as well.

Conversely, when designers show users that they have misrecognized the social value of technologies, this can lead users to see themselves as having been misrecognized by designers as well. For example, when Boston Dynamics posted videos of tests of their new humanoid robot Atlas, these tests were described by one journalist as "bullying" (Titcomb 2016), and another writes, "If you did feel uncomfortable watching the robot get pushed around, congratulations on having a well-developed sense of empathy" (Stockton 2016). Though both journalists joked that the designers were wrong to bully Atlas because it would lead to a "robot uprising," from a Hegelian perspective we can now see that it is wrong for designers to bully Atlas because they 
are not giving Atlas the respect it deserves, respect it deserves precisely because we are able to recognize Atlas as vulnerable, as a moral being capable of being bulled in the first place.

Furthermore, we can now also see that the uprising we should worry about is not of robots, but of those who serve functionally equivalent roles to robots. To recognize robots as mistreated by society is to have begun the process of becoming conscious of oneself as mistreated by society, the proof of which can be seen in our projecting onto robots the very desire to rise up against society. Thus beyond the worry of designers misrecognizing technologies, there is the more pressing worry of institutions misrecognizing technologies. From the perspective of the Dallas police department, their EOD robot was a tool, and transforming the robot into a remotecontrol killing machine was merely a means to an end. From the perspective of the military, the EOD robot is a quasi-comrade, for which reason we can understand why at least one veteran was "extremely disturbed and opposed" (Gertz 2016) to this transformation. The fear of soldiers of being seen by society as nothing more than mere tools, as mere tools who can be used to save lives or take lives depending on the circumstances, was realized in not only the Dallas PD's transformation of the EOD robot, but in the subsequent debate (or lack thereof) concerning whether this transformation was acceptable. That the EOD robot was used by the police to kill a sniper who was a veteran only further illuminates how vital it is to understand the roles that technologies play in ethical and political life.

To achieve this understanding we must begin by realizing that to recognize technologies is to recognize ourselves, and that to misrecognize technologies is to misrecognize ourselves. For Verbeek, because technologies mediate our practices, technologies play a role in ethical life whether we want to admit it or not, for which reason we must take up the responsibility of trying to predict and shape mediations in an ethical way. As Verbeek concludes, "Material artifacts, and 
especially the technological devices that increasingly inhabit the world in which we live, deserve a place at the heart of ethics. Just like human beings, albeit in a different way, they belong to the moral community" (Verbeek 2011: 165). However, from a Hegelian perspective, we can only give technologies the place in both ethical and political life that they deserve if we recognize that technologies "belong to the moral community," but not "in a different way" from human beings. We are not moral beings because we are human. We are human because we are moral beings. To extend this Hegelian insight to technologies by recognizing them as moral beings is not to anthropomorphize technologies, but to take seriously what it means to be in hybridized relationships with technologies, to relate to technologies as an " $\mathrm{I}$ ' that is 'We' and 'We' that is 'I'”' (Hegel 1997: 110).

\section{Reference List}

Aristotle. 2000. Nicomachean Ethics. Ed. R. Crisp. Cambridge: Cambridge University Press. Boshuijzen-van Burken, Christine. 2016. "Beyond technological mediation: a normative practice approach,” Techné: Research in Philosophy and Technology, 20(3): 177-197.

Bostrom, Nick. 2005. "In defense of posthuman dignity,” Bioethics, 19(3): 202-214.

Bryson, Joanna. 2010. "Robots should be slaves.” In Close Engagements with Artificial Companions, ed. Yorick Wilks, 63-74. Amsterdam/Philadelphia: John Benjamins Publishing Company.

Coeckelbergh, Mark. 2015. "The tragedy of the master: automation, vulnerability, and distance," Ethics and Information Technology, 17(3): 219-229.

Coeckelbergh, Mark. 2016. “Alterity Ex Machina.” In The Changing Face of Alterity, eds. David Gunkel, Ciro Marcondes Filho, and Dieter Mersch, 181-196. London/New York: Rowman \& 
Littlefield International.

Danahay, Martin A. and Rieder, David. 2002. “The Matrix, Marx, and the Coppertop's Life.” In The Matrix and Philosophy, ed. William Irwin, 216-224. Chicago: Open Court.

Ellul, Jacques. 1964. The Technological Society. Trans. J. Wilkinson. New York: Vintage.

Floridi, Luciano. 2017. "Roman law offers a better guide to robot rights than sci-fi," Financial

Times, https://www.ft.com/content/99d60326-f85d-11e6-bd4e-68d53499ed71. Accessed 14

March 2017.

Fountain, Henry and Schmidt, Michael S. 2016. “'Bomb Robot' Takes Down Dallas Gunman, but Raises Enforcement Questions," The New York Times, https://www.nytimes.com/2016/07/09/science/dallas-bomb-robot.html. Accessed 18 January 2017.

Garber, Megan. 2013. "Funerals for Fallen Robots," The Atlantic, http://www.theatlantic.com/technology/archive/2013/09/funerals-for-fallen-robots/279861/. Accessed 18 January 2017.

Gertz, Nolen. 2014. The Philosophy of War and Exile. Basingstoke: Palgrave-Macmillan. Gertz, Nolen. 2016. "Death by Robot: The Ethics of Turning Assistive Technologies into Assassins," ABC Religion and Ethics, http://www.abc.net.au/religion/articles/2016/07/12/4499213.htm. Accessed 18 January 2017.

Gunkel, David J. 2012. The Machine Question. Cambridge: The MIT Press.

Hacking, Ian. 2007. “Our neo-Cartesian bodies in parts,” Critical Inquiry 34: 78-105.

Hegel, Georg Wilhelm Friedrich. 1977. Hegel's Phenomenology of Spirit. Trans. A. V. Miller. Oxford: Oxford University Press.

Heidegger, Martin. 1988. Hegel's Phenomenology of Spirit. Trans. P. Emad and K. Maly. 
Bloomington: Indiana University Press.

Honneth, A. (1995). The Struggle for Recognition. Trans. J. Anderson. Cambridge: The MIT Press.

Ihde, D. (1990). Technology and the Lifeworld. Bloomington: Indiana University Press.

Kojève, Axel. 1980. Introduction to the Reading of Hegel. Trans. J. J. Nichols, Jr. Ithaca: Cornell University Press.

Latour, Bruno. 1992. "Where Are the Missing Masses? The Sociology of a Few Mundane Artifacts.” In Shaping Technology/Building Society, ed. W. E. Bijker and J. Law, 225-258. Cambridge: MIT Press.

Rosenberger, Robert and Verbeek, Peter-Paul. 2015. “A Field Guide to Postphenomenology.” In Postphenomenological Investigations, ed. R. Rosenberger and P.-P. Verbeek, 9-41. London: Lexington Books.

Singer, Peter W. 2009. Wired for War. New York: The Penguin Press.

Stern, Robert. 2002. Hegel and the Phenomenology of Spirit. London/New York: Routledge. Stern, Robert. 2012. “Is Hegel's Master-Slave Dialectic a Refutation of Solipsism?”, British Journal for the History of Philosophy, 20(2): 333-361.

Stockton, Nick. 2016. “Boston Dynamics' New Robot is Wicked Good at Standing Up to Bullies," Wired, http://www.wired.com/2016/02/boston-dynamics-new-robot-wicked-goodgetting-bullied/. Accessed online: 2 April 2016.

Titcomb, James. 2016. "Boston Dynamics' terrifying new robot endures bullying from human masters," The Telegraph, http://www.telegraph.co.uk/technology/2016/02/24/boston-dynamicsterrifying-new-robot-endures-bullying-from-human/. Accessed online: 2 April 2016. Tromp, Nynke, Hekkert, Paul, and Verbeek, Peter-Paul. 2011. "Design for Socially Responsible 
Behavior: A Classification of Influence Based on Intended User Experience," Design Issues, 27(3): 3-19.

Verbeek, Peter-Paul. 2011. Moralizing Technology. Chicago: The University of Chicago Press. Wallach, Wendell. 2015. A Dangerous Master: How to Keep Technology from Slipping Beyond Our Control. New York: Basic Books.

Weberman, David. 2002. "The Matrix Simulation and the Postmodern Age." In The Matrix and Philosophy, ed. William Irwin, 225-239. Chicago: Open Court. 